\title{
A METHOD FOR THE DETERMINATION OF HEAT PRODUCTION OVER LONG PERIODS OF TIME ${ }^{1}$
}

\author{
By L. H. NEWBURGH, F. H. WILEY ${ }^{2}$ aNd F. H. LASHMET \\ (From the Department of Internal Medicine, Medical School, University of Michigan, \\ Ann Arbor)
}

(Received for publication May 22, 1931)

Heretofore, it has not been possible to measure the heat production of individuals leading their usual lives, due to the unavoidable restrictions necessary to carry out either direct or indirect calorimetry. It is quite obvious that the movements of a subject in a calorimeter are sharply restricted by the capacity of the apparatus and, hence, prevent normal activity. On the other hand, the value of determinations based on indirect calorimetry depends on sampling in such a way that the expired air thus collected is really representative of the period, and there is no way of knowing whether this is the case. Further, the sampling necessarily requires the individual to be at rest for frequent ten minute periods and so disturbs his usual routine. The method which we are proposing is not hampered by either of these two restrictions.

In an earlier paper (1) it was pointed out that the insensible loss of weight is roughly proportional to the heat production of the period, provided two sources of error are excluded; namely, first, there must be a proper relationship between the rate of heat production and the environmental conditions, and, secondly, the subject must be transforming a minimal amount of energy to mechanical work. In the previous paper it was also shown that the insensible loss of weight is the resultant of the weight of water lost by evaporation, the weight of exhaled carbon dioxide and the weight of absorbed oxygen. The relationship can be conveniently expressed as an equation:

$$
\text { Insensible loss of weight }=\mathrm{H}_{2} \mathrm{O}+\mathrm{CO}_{2}-\mathrm{O}_{2} \text {. }
$$

1 The expenses of this investigation were defrayed in part by a fund for the study of nutrition created by Mr. W. K. Kellogg, of the Kellogg Corn Flake Company, Battle Creek, Michigan.

2 National Research Council Fellow in Medicine. 
The numerical relationship of the three factors making up the insensible loss of weight was discussed and it was shown that, given constant weight of vaporized water, the insensible loss of weight varies with the respiratory quotient. ${ }^{3}$ Since the vaporization of water is the only factor in insensible loss of weight that removes heat from the body, it, and not the total insensible loss, should be used when dealing with the dissipation of heat. Furthermore, it is true that the dissipation of heat keeps pace with the heat production when there is no change in body temperature and, that the heat production is equal to the total energy transformations when no energy is being converted to mechanical work. Accordingly, if a fixed per cent of the total heat produced is carried away by evaporation of water, then the weight of this water vapor may be used as a measure of the total heat production, or its equivalent, in the absence of mechanical work, ${ }^{4}$ the total transformation of energy.

\begin{tabular}{|c|c|c|}
\hline${ }^{3}$ Respiratory quotient & $\begin{array}{c}\begin{array}{c}\text { Insensible } \\
\text { water } \\
\text { grams } \\
978\end{array} \\
978\end{array}$ & $\begin{array}{c}\text { Insensible } \\
\text { loss of weight } \\
\text { grams } \\
1193\end{array}$ \\
\hline $0.82 \ldots \ldots$ & .. 978 & 1054 \\
\hline $0.707 \ldots$ & . . 978 & 940 \\
\hline
\end{tabular}

4 "Mechanical work." This term as used in calorimetry means the transfer of energy from one system to another. The animal body is made up of two systems, one, the mass of the body and, two, a machine for transforming energy. Therefore, the organism may either do work upon itself, i.e. its mass, or upon some external object. Horizontal motion on the part of the animal organism is accompanied by a negligible amount of mechanical work since the resistance to this type of motion is very small. On the other hand, vertical motion requires mechanical work in proportion to the product of weight and distance. In this case all of the energy transformed does not appear as heat, since some of it is stored as energy of position. But in the course of the day's routine, he who goes up comes down again, and this energy of position is lost in the form of heat. Only when the individual is further from the center of gravity at the end of the period than he was at the beginning, has he stored any extra energy of position in himself.

When an individual lifts a weight to a higher position, and leaves it there, or when he supplies the energy to drive a machine, he does mechanical work. The heat equivalent of mechanical work is very small. One calorie will lift $427 \mathrm{kgm}$. one meter. It is accordingly evident that, excepting those who earn their livelihood as laborers, human beings do not convert a significant amount of the energy liberated in the body to mechanical work. 
The experiments now to be described were designed to determine whether an individual leading his normal existence would lose a fixed per cent of his total heat production by the vaporization of water. The weight of the vaporized water was multiplied by 0.58 to get its equivalent in heat units and this latter value was then compared percentilely with the total heat production.

In order to compare the heat dissipated by vaporization of water with the total heat produced it was, of course, essential to know how much heat was produced. The energy transformations of an individual who has been on a constant diet for a long period of time will necessarily come into balance with the diet, and thereafter the heat production will equal the available energy of the diet. If an individual whose food has been unrestricted is now placed on a diet whose available energy is not far from his metabolic needs, his transformations of energy will shortly be in balance with the energy of the diet. When this point has been reached the observer will have at hand a knowledge of the average heat production of the individual. If he now obtains the weight of the water vaporized it will be a simple matter to calculate what proportion of the transformed energy was lost in this manner.

Day to day changes in body weight cannot be used to decide whether the subject's transformation of energy is greater or less than the available energy of the diet due to the irregular hydration and dehydration of the tissues. On the other hand the trend of the weight is significant. A persistent loss or gain in the body weight over a long period of time can be taken to indicate a loss or deposition of body tissue. The longer the individual has adhered to a fixed plan the greater the probability that his energy transformations will be the same as the inflow of energy.

After the subject is in balance with a diet, it is necessary to know as closely as possible what the actual energy value of the diet is. Repeated analyses in this laboratory over a number of years have shown that the available energy of the ordinary mixed diet, prepared in our special diet kitchen, is two to three per cent less than the prescribed value. The major part of this deficiency occurs in the fat portion (probably due to loss in serving).

After we had taken pains to arrive at as close a value as possible for 
the heat production, it became necessary to determine what per cent of this heat was dissipated by the evaporation of water. We first obtained the twenty-four hourly insensible loss of weight by the following equation:

(1) Beginning weight ${ }^{5}$ - (end weight - ingesta + urine and stool). The nature of this insensible loss of weight may also be expressed as an equation:

(2) Insensible loss of weight

$$
\text { = weight of water vapor }+ \text { weight of } \mathrm{CO}_{2}-\text { weight of } \mathrm{O}_{2} \text {. }
$$

Of these three constituents, the water vapor alone removes heat from the body. When its weight is known one is in possession of a measure of the amount of heat lost by the vaporization of water. Thus far the only value in equation (2) which is known is the insensible loss of weight. Two other values, namely, the weights of the carbon dioxide and oxygen, may be calculated from the metabolic mixture, by means of the following constants:

\begin{tabular}{|c|c|c|c|}
\hline Material oxidized & $\begin{array}{c}\text { Carbon dioxide } \\
\text { produced per gram }\end{array}$ & $\begin{array}{l}\text { Oxygen absorbed } \\
\text { per gram }\end{array}$ & $\begin{array}{l}\text { Carbon dioxide } \\
\text { minus oxygen }\end{array}$ \\
\hline Protein. & 1.46 & 1.38 & +0.08 \\
\hline Fat.......... & 2.78 & 2.86 & -0.08 \\
\hline Carbohydrate........ & 1.54 & 1.13 & +0.41 \\
\hline
\end{tabular}

In these studies the metabolic mixture is the same as, or very close to, the composition of the diet.

Eight people, of whom two were females, were used as subjects. They consisted of two graduate chemical students, one medical student, two professional chemists (one of whom was a female), and two male and one female diabetics. One male diabetic lived quietly in the neighborhood of the hospital. The other was an interne. The female diabetic was a nurse in charge of an outpatient clinic. All subjects were instructed to continue the usual routine of life, but to avoid sensible perspiration as far as possible. It should be emphasized that there were no other restrictions imposed on the subjects.

5 A simple beam balance capable of quickly weighing human subjects to one gram was built for us by "Henry Troemner, Philadelphia." This manufacturer is prepared to supply such balances. 
The three diabetic subjects had been on a fixed weighed diet for one or more years, and were therefore especially valuable for the work. The remainder of the subjects were placed on diets that were thought to meet their needs. We arrived at this opinion in the following manner: The heat dissipated by the vaporization of water in the case of the diabetic who had been on a fixed diet for the longest period of time, was obtained for a number of days and found to be about 24 per cent of the total available energy of the diet. Since this value coincides with figures obtained in the calorimeter (2), for the removal of heat by vaporization of water, it was provisionally assumed that human beings regularly lose 24 per cent of their heat in this way. Accordingly, the five non-diabetic subjects started eating meals prepared in the diet kitchen, in order to enable us to determine the heat removed by vaporization of water for a week or longer. This value was assumed to represent 24 per cent of their metabolic requirement, and the diet was constructed accordingly. Four of these five subjects continued to receive this diet for more than two months, and the fifth one for only eighteen days.

Subject I. F.D.J. Male, diabetic, age 30, weight $56 \mathrm{kgm}$., height 174 $\mathrm{cm}$., basal metabolism 1550 Calories. This subject had been eating a fixed weighed diet in the hospital for five years without showing any significant changes in body weight. Without any interference with this diet, or his daily routine, his twenty-four hourly insensible loss was determined over a five-day period. His diet had the following composition: 57.7 grams of protein, 273.6 grams of fat, 63.4 grams of carbohydrate, giving 2,947 Calories. The oxygen required to burn these substances was 932 grams, and the carbon dioxide produced was 942 grams, the difference being 10 grams per day. The average twenty-four hourly insensible loss of weight was 1235 grams. Hence, the insensible water was $1225(1235-10)$. This value multiplied by 0.58 gives the dissipation of heat by evaporation of water for twenty-four hours. It was 711 Calories, which is 24.2 per cent of the total heat production.

Subject II. L.R. Female, diabetic, age 35 years, height $153.5 \mathrm{~cm}$., weight $53 \mathrm{kgm}$., basal metabolism 1140 Calories. This subject had been on a weighed diabetic diet for nineteen months when the experiment was undertaken. In May, 1929, when the diagnosis was made, she weighed $57.5 \mathrm{kgm}$. and was placed on an 1800 Calorie diabetic diet. She gradually lost weight on this plan, so that six months later she weighed $51 \mathrm{kgm}$. Thereafter for 257 days her average daily intake of energy was $2200 \mathrm{Cal}$ ories, with an accompanying increase of weight to $56 \mathrm{kgm}$. Then for a 
period of sixty-nine days she received 2000 Calories per day and her weight again fell to $53.6 \mathrm{kgm}$. Accordingly, this subject lost weight on diets containing 1800 and 2000 Calories per day and gained weight when the energy intake was 2200 Calories per day. A consideration of these values suggests that she was transforming energy at a rate of more than 2000 Calories and less than 2100 Calories per day.

She was now placed on the same type of diet whose energy value was 2000 Calories, and the first period, during which the twenty-four hourly insensible loss of weight was determined, began on the morning of December 22, 1930. She remained on this diet for eighty-five days and lost $1.1 \mathrm{kgm}$., or 13 grams per day. Table I sets forth the data.

TABLE I

The relationship between total heat production and the insensible loss of water, Subject II

\begin{tabular}{|c|c|c|c|c|c|}
\hline $\begin{array}{c}\text { Days on } \\
\text { diet }\end{array}$ & $\begin{array}{c}\text { Daily insensible } \\
\mathrm{H}_{2} \mathrm{O}\end{array}$ & $\begin{array}{c}\text { Days on } \\
\text { diet }\end{array}$ & $\begin{array}{c}\text { Daily insensible } \\
\mathrm{H}_{2} \mathrm{O}\end{array}$ & $\begin{array}{c}\text { Days on } \\
\text { diet }\end{array}$ & $\begin{array}{c}\text { Daily insensible } \\
\qquad \mathrm{H}_{2} \mathrm{O}\end{array}$ \\
\hline 1 & $\begin{array}{l}\text { grams } \\
1044\end{array}$ & 22 & $\begin{array}{l}\text { grams } \\
1125\end{array}$ & 79 & $\begin{array}{l}\text { grams } \\
1059\end{array}$ \\
\hline 2 & 666 & 23 & 1167 & 80 & 1124 \\
\hline 3 & 876 & 24 & 1066 & 81 & 1176 \\
\hline 5 & 916 & 25 & 956 & 82 & 1033 \\
\hline 6 & 930 & 26 & 966 & 83 & $948 \dagger$ \\
\hline 7 & 840 & 27 & 966 & 84 & 1011 \\
\hline \multirow[t]{2}{*}{8} & $1222^{*}$ & 28 & 825 & 85 & 913 \\
\hline & & 29 & 956 & & \\
\hline Averages.... & 970 & & 1003 & & 1037 \\
\hline
\end{tabular}

Diet $(2000$ Calories $)+$ body fat $(75$ Calories $)=2075$ Calories transformed. Average insensible water $=1003$ grams.

$1003 \times 0.58=582$ Calories dissipated by vaporization.

$\frac{582}{2075}=28.0$ per cent of total heat removed.

Weight on first day of diet: $52.6 \mathrm{kgm}$.

Weight on last day of diet: $52.4 \mathrm{kgm}$.

* Extra work. (Not included in average.)

† Sunday.

Subject III. T.M. Male, diabetic, age 56 years, weight $70 \mathrm{kgm}$. , height $180 \mathrm{~cm}$., basal metabolism 1640 Calories. This subject had been on a weighed diabetic diet containing about 2525 Calories per day for six months, without any significant change in body weight. On December 31, 
1930, when his weight was $70.58 \mathrm{kgm}$., his diet was changed so it contained about 2425 Calories. In twenty days on this diet his loss of weight was $2.8 \mathrm{kgm}$., half of which was lost on the first day. He was then returned to his original diet and in fifty-two days he gained $1.5 \mathrm{kgm}$. From these figures it is obvious that his transformation of energy is about 2500 Calories per day. His average insensible water (Table II), omitting days on which

TABLE II

The relationship between total heat production and the insensible loss of water, Subject III

\begin{tabular}{|c|c|c|c|c|c|c|c|c|c|}
\hline $\begin{array}{l}\text { Days } \\
\text { on } \\
\text { diet }\end{array}$ & $\mid \begin{array}{c}\text { Daily } \\
\text { insensible } \\
\mathrm{H}_{2} \mathrm{O}\end{array}$ & $\begin{array}{c}\text { Days } \\
\text { on } \\
\text { diet }\end{array}$ & $\mid \begin{array}{c}\text { Daily } \\
\text { insensible } \\
\mathrm{H}_{2} \mathrm{O}\end{array}$ & $\begin{array}{l}\text { Days } \\
\text { on } \\
\text { diet }\end{array}$ & $\mid$\begin{tabular}{|c|} 
Daily \\
insensible \\
$\mathbf{H}_{2} \mathrm{O}$
\end{tabular} & $\begin{array}{l}\text { Days } \\
\text { on } \\
\text { diet }\end{array}$ & $\underset{\substack{\text { Daily } \\
\text { insensible } \\
\mathrm{H}_{2} \mathrm{O}}}{ }$ & $\begin{array}{c}\text { Days } \\
\text { on } \\
\text { diet }\end{array}$ & $\begin{array}{c}\text { Daily } \\
\text { insensible } \\
\mathrm{H}_{2} \mathrm{O}\end{array}$ \\
\hline 1 & $\begin{array}{c}\text { grams } \\
1018\end{array}$ & 8 & $\begin{array}{c}\text { grams } \\
882^{*}\end{array}$ & 15 & $\begin{array}{c}\text { grams } \\
833^{*}\end{array}$ & 63 & $\begin{array}{l}\text { grams } \\
1178\end{array}$ & 70 & $\begin{array}{r}\text { grams } \\
967\end{array}$ \\
\hline 2 & 957 & 9 & 1009 & 16 & $904^{*}$ & 64 & 913 & 71 & 1077 \\
\hline 3 & 990 & 10 & 1055 & 17 & $929^{*}$ & 65 & 1056 & 72 & 923 \\
\hline 4 & 1143 & 11 & 1065 & 18 & 929* & 66 & 1033 & & \\
\hline 5 & $878^{*}$ & 12 & 1014 & 19 & 1045 & 67 & 1151 & & \\
\hline 6 & 1083 & 13 & 1011 & 20 & 954 & 68 & 933 & & \\
\hline 7 & 1059 & 14 & $846^{*}$ & 21 & $860^{*}$ & 69 & 957 & & \\
\hline Averages & 1042 & & 1031 & & & & 1031 & & \\
\hline
\end{tabular}

Diet (2500 Calories) $=$ Calories transformed.

Average insensible water $=1026$ grams.

$1026 \times 0.58=595$ Calories dissipated by vaporization.

$\frac{595}{2500}=23.8$ per cent of total heat removed.

Weight on first day of diet: $70.6 \mathrm{kgm}$.

Weight on last day of diet: $70.2 \mathrm{kgm}$.

* Too cold. (Not included in average.)

he was known to have been too cold, was 1026 grams per day. This value multiplied by 0.58 indicates a loss of 595 Calories per day by the vaporization of water, which is 23.8 per cent of the total heat production.

Subject IV. R.L.G. Male, graduate student, age 24 years, weight 66 $\mathrm{kgm}$., height $174 \mathrm{~cm}$., basal metabolism 1700 Calories. His average insensible loss of weight over a period of one week suggested that he was transforming about 3600 Calories per twenty-four hours. Accordingly, a diet containing 3700 Calories was prescribed. Recalculation according to the principles discussed above indicated that he was actually receiving close to 3650 Calories per twenty-four hours. He remained on this diet for sixtyeight days. During these sixty-eight days he added 1000 grams to his body 
weight. If this were solely adipose tissue he would have deposited 125 Calories daily in that form. However, it is probably true that some glycogen and protein were also deposited. These substances per gram of wet weight contain much less energy than adipose tissue. It would be safe to assume that the subject transformed 100 fewer Calories than the energy available in the diet. (See Table III.)

TABLE III

The relationship between total heat production and the insensible loss of water, Subject IV

\begin{tabular}{|c|c|c|c|c|c|}
\hline $\begin{array}{c}\text { Days on } \\
\text { diet }\end{array}$ & $\begin{array}{l}24 \text { hourly insen- } \\
\text { sible } \mathrm{H}_{2} \mathrm{O}\end{array}$ & $\begin{array}{c}\text { Days on } \\
\text { diet }\end{array}$ & $\begin{array}{l}24 \text { hourly insen- } \\
\text { sible } \mathrm{H}_{2} \mathrm{O}\end{array}$ & $\begin{array}{c}\text { Days on } \\
\text { diet }\end{array}$ & $\begin{array}{l}24 \text { hourly insen- } \\
\text { sible } \mathrm{H}_{2} \mathrm{O}\end{array}$ \\
\hline 22 & $\begin{array}{l}\text { grams } \\
1813\end{array}$ & 36 & $\begin{array}{l}\text { grams } \\
1442\end{array}$ & 62 & $\begin{array}{l}\text { grams } \\
1581\end{array}$ \\
\hline 23 & 1605 & 37 & 1467 & 63 & $1927 \dagger$ \\
\hline 24 & 1655 & 38 & 1542 & 64 & 1657 \\
\hline 25 & 1639 & 39 & 1504 & 65 & $1253_{+}^{+}$ \\
\hline 26 & 1451 & 40 & $1362 *$ & 66 & 1730 \\
\hline 27 & 1456 & 41 & 1534 & 67 & 1602 \\
\hline 28 & $1679^{\circ}$ & 42 & 1663 & 68 & 1437 \\
\hline Averages..... & 1614 & & 1502 & & 1551 \\
\hline
\end{tabular}

Diet (3650 Calories) - deposition (100 Calories) $=3550$ Calories transformed.

Average insensible water $=1544$ grams. $\$$

$1544 \times 0.58=895$ Calories dissipated by vaporization.

$\frac{895}{3550}=25.2$ per cent of total heat removed.

Weight on first day of diet: $66.5 \mathrm{kgm}$.

Weight on last day of diet: $67.5 \mathrm{kgm}$.

* Sunday.

$\dagger$ Sweat. (Not included in average.)

$\ddagger$ Afternoon nap.

$\S$ Insensible water; 1614 for 14 days; 1526 for 54 days.

Subject V. A.W. Graduate student, male, age 23 years, weight 63.5 kgm., height $165 \mathrm{~cm}$., basal metabolism 1600 Calories. His average insensible loss of weight over a period of ten days suggested that he was transforming about 3600 Calories for twenty-four hours. Accordingly he received a diet containing 3650 Calories in twenty-four hours. He remained on this diet for sixty-five days. During this period he gained 800 grams, which, according to the principles discussed under Subject IV, indicates a deposition of about 80 Calories daily. The data are to be found in Table IV. 
TABLE IV

The relationship between total heat production and the insensible loss of water, Subject $V$

\begin{tabular}{|c|c|c|c|c|c|c|c|}
\hline $\begin{array}{c}\text { Days } \\
\text { on } \\
\text { diet }\end{array}$ & $\begin{array}{c}24 \text { hourly } \\
\text { insensible } \\
\mathrm{H}_{2} \mathrm{O}\end{array}$ & $\begin{array}{c}\text { Days } \\
\text { on } \\
\text { diet }\end{array}$ & $\begin{array}{c}24 \text { hourly } \\
\text { insensible } \\
\mathrm{H}_{2} \mathrm{O}\end{array}$ & $\begin{array}{c}\text { Days } \\
\text { on } \\
\text { diet }\end{array}$ & $\begin{array}{c}24 \text { hourly } \\
\text { insensible } \\
\mathrm{H}_{2} \mathrm{O}\end{array}$ & $\begin{array}{c}\text { Days } \\
\text { on } \\
\text { diet }\end{array}$ & $\begin{array}{c}24 \text { hourly } \\
\text { insensible } \\
\mathrm{H}_{2} \mathrm{O}\end{array}$ \\
\hline 20 & $\begin{array}{c}\text { grams } \\
1827\end{array}$ & 34 & $\begin{array}{c}\text { grams } \\
1539\end{array}$ & 38 & $\begin{array}{l}\text { grams } \\
1314^{*}\end{array}$ & 59 & $\begin{array}{c}\text { grams } \\
1529\end{array}$ \\
\hline 21 & 1515 & 35 & 1723 & 39 & 1385 & 60 & $1714 \ddagger$ \\
\hline 22 & 1505 & 36 & 1715 & 40 & 1439 & 61 & $1766^{\circ}$ \\
\hline 23 & 1673 & 37 & 1640 & 41 & $1648 \dagger$ & 62 & 1279 \\
\hline 24 & 1581 & & & 42 & 1402 & 63 & 1510 \\
\hline 25 & 1439 & & & 43 & 1352 & 64 & 1698 \\
\hline 26 & 1776 & & & 44 & 1492 & 65 & 1688 \\
\hline Averages & 1617 & & 1654 & & 1433 & & 1578 \\
\hline
\end{tabular}

Diet (3650 Calories) - deposition ( 80 Calories) $=3570$ Calories transformed.

Average insensible water $=1538$ grams.

$1538 \times 0.58=882$ Calories dissipated by vaporization.

$\frac{882}{3570}=24.7$ per cent of total heat removed.

Weight on first day of diet: $63.7 \mathrm{kgm}$.

Weight on last day of diet: $64.5 \mathrm{kgm}$.

* Very quiet day.

$\dagger 3$ hours sleep.

$\ddagger$ Perspiration. (Not included in the average.)

Subject VI. M.P. Medical student, male, age 25 years, weight 67.3 kgm., height $175 \mathrm{~cm}$., basal metabolism 1695 Calories. This subject was placed on a diet of 3425 Calories and left on it throughout the study. During the first thirty-five days there was no significant change in weight. Two weekly periods of insensible water were obtained during this interval. Table $\mathrm{V}$ sets forth this data. During a subsequent period of thirty-two days he gained 1400 grams. Both the subject and we were aware that he was less active throughout this interval. The average insensible water for a week at the end of the second period was 1296 grams, indicating a transformation of 3150 Calories and permitting a deposition of 275 Calories daily. This decrease in insensible water is significant, since the gain in weight without change of diet indicated a diminished transformation of energy.

Subject VII. M.W. Female chemist, age 24 years, weight $73 \mathrm{kgm}$., height $168 \mathrm{~cm}$., basal metabolism 1615 Calories. This subject was put on a diet containing about 2800 Calories, and the daily insensible loss of weight 
TABLE V

The relationship between total heat production and the insensible loss of water, Subject VI

\begin{tabular}{c|c||c|c}
\hline Days on diet & Daily insensible $\mathrm{H}_{2} \mathrm{O}$ & Days on diet & Daily insensible $\mathrm{H}_{2} \mathrm{O}$ \\
\cline { 2 - 3 } 1 & grams & 28 & grams \\
1357 & 29 & 1383 \\
2 & 1292 & 30 & 1423 \\
3 & 1415 & 31 & $1700^{*}$ \\
4 & 1349 & 33 & 1501 \\
5 & 1411 & 34 & 1447 \\
6 & 1645 & 35 & 1413 \\
7 & 1518 & & 1512 \\
\hline
\end{tabular}

Diet (3425 Calories) = Calories transformed.

Average insensible water $=1425$ grams.

$1425 \times 0.58=826.5$ Calories dissipated by vaporization.

$\frac{826}{3425}=24.1$ per cent of total heat removed.

Weight on first day of diet: $67.3 \mathrm{kgm}$.

Weight on last day of diet: $67.6 \mathrm{kgm}$.

* Additional activity. (Not included in average.)

was obtained for one week. It indicated, on the assumption that 24 per cent of the heat production was dissipated by the vaporization of water, that her daily transformation of energy was about 3230 Calories. During this period she lost weight very sharply.

She was then placed on a diet containing about 3150 Calories. Her weight did not change significantly during the next two weeks, at which time she acquired an acute infection, causing the experiment to be interrupted for sixteen days. During this interval she gained weight. She now began to live on the experimental diet again, and her weight at the beginning was $73.68 \mathrm{kgm}$. She lost weight slowly on this diet, as was to be expected, since the insensible loss of water for a second period of one week indicated a transformation of 3215 Calories per day. After two weeks on this diet, her calorific intake was increased to 3225 Calories. After four weeks on this last diet, her weight was back to the original level. These considerations indicate that an average daily intake of 3210 Calories was necessary for maintenance of weight.

Subject VIII. Male chemist, age 28 years, height $183 \mathrm{~cm}$., weight 57 $\mathrm{kgm}$., basal metabolism 1470 Calories. This subject was placed on a diet containing 2922 Calories per day. Since this period was to be used as the 
TABLE VI

The relationship between total heat production and the insensible loss of water, Subject VII.

\begin{tabular}{c|c||c|c}
\hline \hline Days on diet & Daily insensible $\mathrm{H}_{2} \mathrm{O}$ & Days on diet & Daily insensible $\mathrm{H}_{2} \mathrm{O}$ \\
\hline & grams & & grams \\
1 & 1433 & 38 & 1435 \\
2 & $1769^{*}$ & 39 & 1253 \\
3 & 1190 & 40 & 1500 \\
4 & 1348 & 41 & 1220 \\
5 & 1439 & 42 & 1363 \\
6 & 1135 & 43 & 1585 \\
7 & 1434 & 44 & 1220 \\
\hline
\end{tabular}

Diet $(3210$ Calories $)=$ Calories transformed.

Average insensible water $=1349$ grams.

$1349 \times 0.58=781$ Calories dissipated by vaporization.

$\frac{781}{3210}=24.4$ per cent of total heat removed.

Weight on first day of diet: $73.7 \mathrm{kgm}$.

Weight on last day of diet: $73.7 \mathrm{kgm}$.

* Extra work. (Not included in average.)

basis for comparison in another study, we took great pains to get the actual available energy of the diet by use of the bomb calorimeter. He was found to be in nitrogen balance and, since his daily variation in weight was so slight and the total change over a period of eighteen days was only 14 grams, it is safe to conclude that he was also in caloric balance. Calculation of water exchange showed that he was in balance in this respect also, and that a loss or gain of tissue had not been concealed by a shift in water. A graph of his weight record, corrected for daily shifts in water exchange, is a straight line. His total insensible water.for eighteen days was 21,964 grams, and this multiplied by 0.58 gave 12,739 Calories, or 708 Calories per day lost by the vaporization of water. This is 24.2 per cent of the total energy transformation.

\section{DISCUSSION}

Our earlier study (3) in this field clearly showed that (1) the amount of heat lost by the vaporization of water in the nude, resting subject was strikingly affected by the temperature and the humidity of the environment; (2) that the effect of humidity was negligible when the subject was clothed, and that the effect of temperature was less marked; 
and (3) that, in the short basal periods with clothed individuals in the presence of a fixed environmental temperature, the amount of heat lost by the vaporization of water varied from about 20 to 34 per cent of the total heat dissipated. Even though this method is not adapted to measuring heat production accurately for brief intervals of time, there is, a priori, no reason why it should not be successful as a means of obtaining the total exchange of energy over protracted periods.

Our investigations have emphasized the necessity of guarding against two sources of error. We have found that when the individuals become unusually warm, the ratio between the heat lost by vaporization of water and the total heat production increases markedly above the average and returns to the usual value when the condition is corrected. This condition may be due either to an increase in the environmental temperature or to an increase in the heat production, and can often be corrected by an adjustment in the amount of clothing. In any case the individual is generally aware of being uncomfortably warm. For example, in Table III, on the sixty-third day, the subject, following his usual routine, unwittingly wore heavy winter clothing while walking out of doors on a day strikingly warm for the season. He was conscious of perspiring freely and his insensible loss of water rose from an average of 1550 grams per twenty-four hours to 1927 grams. Thus a subject in an experiment of this type should be warned to prevent himself from becoming uncomfortably warm. On the other hand, an unusually large value for the insensible water of a twenty-four hour period does not necessarily mean that the per cent of heat dissipated by it is out of proportion to the average per cent. It may simply be due to an increased heat production. Thus in Table VI, on the second day, the subject moved to a new abode and the accompanying increased activity was reflected in the insensible water for the period.

The opposite effect has been observed when the individual becomes uncomfortably cool. A striking example of this effect is seen in Table II from the fourteenth to the eighteenth day inclusive. During a period of unusually cold weather, the subject was either too obstinate or too indolent to put extra bedding over himself at night. He preferred the alternative of having a series of disturbed nights due to being uncomfortably cool. Obviously this error is more easily avoided than the first. 
All of these subjects were exposed to the wide variations in environmental temperature and humidity between the heated buildings and the cold out of doors during the winter, but they gave no more than the habitual attention to keeping their bodies comfortable. Nevertheless, the daily insensible loss of water for each individual remained within a narrow range.

The individual following his usual routine tends to expend the same amount of energy from week to week rather from day to day. It is accordingly more significant to compare the weekly averages of insensible water than to compare the daily averages. Thus for three individuals whose routine was very constant, the weekly averages were (Table II) : 1042, 1031, 1031; (Table V): 1425, 1426, and (Table VI): 1330,1368 . In the case of the two graduate chemical students there was a change in activity in the middle of the period of observation, and the subjects predicted a smaller insensible loss of water for the latter part of the period. Thus in Table III there is a fall from 1614 grams to 1502 grams and 1551 grams on subsequent weeks, and in Table IV the weekly losses for the first part of the period are 1617 grams and 1654 grams, and in the latter portion of the period they are only 1433 grams and 1578 grams. This is a very satisfactory agreement between the activity of the individual and the dissipation of heat by the vaporization of water.

The average per cent of the heat production removed by the vaporization of water for each individual will be found in Table VII. A

TABLE VII

Percentile relationship between total heat produced and heat removed by vaporization of water

\begin{tabular}{|c|c|c|c|c|}
\hline Subject & $\begin{array}{l}\text { Total trans- } \\
\text { formation } \\
\text { of energy }\end{array}$ & $\begin{array}{c}\text { Heat lost by } \\
\text { evaporation } \\
\text { of } \mathrm{H}_{2} \mathrm{O}\end{array}$ & Surface area & Remarks \\
\hline L.R. . & $\begin{array}{l}\text { calories } \\
2075\end{array}$ & $\begin{array}{c}\text { per cent } \\
28.0\end{array}$ & $\begin{array}{c}\text { square meters } \\
1.49\end{array}$ & Diabetic-Nurse \\
\hline T.M.. & 2500 & 23.8 & 1.89 & Diabetic-Male \\
\hline F.D.J.... & 2995 & 24.2 & 1.67 & Diabetic-Interne \\
\hline F.H.W... & 2920 & 24.2 & 1.73 & Chemist-Male \\
\hline M.W.. & 3150 & 24.4 & 1.79 & Chemist-Female \\
\hline M.P.. & 3425 & 24.1 & 1.81 & Medical Student-Male \\
\hline A.W... & 3650 & 24.7 & 1.69 & Graduate Student-Male \\
\hline R.L.G.. & 3650 & 25.2 & 1.80 & Graduate Student-Male \\
\hline
\end{tabular}


survey of the table shows that the results from all but one of the eight subjects fall within rather narrow limits. In the case of L.R., we soon recognized that her occupation was such that bursts of intense extra effort could not be avoided and these periods were undoubtedly accompanied by sweating. Obviously, then, the method is not applicable to an individual under these conditions. Accordingly, we shall omit from further considerations the figures obtained in this case. The average value for the remaining seven is 24.4 per cent. Thus each of seven of the subjects, the data from whom appeared to be satisfactory, dissipated very close to 24 per cent of the total heat by the vaporization of water. On the basis of these results we feel that the measurement of insensible loss of water, observing the precautions set forth above, furnishes a satisfactory determination of the total exchange of energy in the case of the unrestricted individual.

At present there is no reason for believing that this method is not applicable to patients lying comfortably in bed, but no data are at hand. Whether the method has any value in febrile or painful disease, is not known.

\section{APPLICATION}

It has been pointed out above that the weight of the vaporized water is proportional to the energy exchange, and that this weight may be calculated from the insensible loss of weight when the weight of carbon dioxide and oxygen is known. Since we strove to feed this group of subjects a diet whose calorific value equaled the heat production, it was a simple matter to calculate the carbon dioxide and the oxygen values directly from the composition of the diets by means of the constants listed on page 706 .

However, it is also quite possible to calculate the carbon dioxide and oxygen exchange of an individual on any diet, or even in starvation, provided the magnitude of the carbohydrate ingestion is known and the nitrogen excretion is determined. The procedure for arriving at the difference between the weights of carbon dioxide and oxygen, and the magnitude of the heat production, for a period under any of these conditions, may be conveniently illustrated by means of hypothetical examples.

I. Starvation. Within the first few days of starvation, the liver glycogen has been destroyed. Thereafter, the metabolic mixture con- 
sists of protein and fat, the protein of which can be determined from the nitrogen excretion. The remainder of the energy comes from the oxidation of fat.

An individual is assumed to lose 912 grams insensibly in twenty-four hours, and to excrete 8.1 grams of nitrogen during this time. The protein destruction is therefore $\mathbf{5 0 . 6}$ grams and 202 Calories were liberated from it. Since the subject is starving, the respiratory quotient will be close to 0.72 . At that quotient the weight of the carbon dioxide equals that of the oxygen; hence, under these conditions, the insensible loss of weight is made up entirely of the weight of the insensible water. Accordingly, the insensible loss of weight during starvation may be used directly to get the first approximation of the energy exchange for the period. Thus:

(1) $\frac{912 \times 0.58}{0.24}=2204$ Calories energy exchange. (First approximation.)

(2) $2204-202=2002$ Calories from fat. (First approximation.)

(3) $\frac{2002}{9.54}=210$ grams fat. (First approximation.)

(4) $\mathrm{CO}_{2}-\mathrm{O}_{2}$ :

50.6 (protein) $\times 0.08=4.0$ grams

210 (fat) $\times(-0.08)=-17.0$ grams

-13.0 (Second approximation.)

(5) 912 (Insensible loss) $-(-13)=925$ Insensible water.

(Second approximation.)

(6) $\frac{925 \times 0.58}{0.24}=2236$ Calories energy exchange. $\begin{aligned} & \text { (Second ap- } \\ & \text { proximation.) }\end{aligned}$

The second approximation yields a sufficiently accurate answer, since the third approximation will be within 0.5 per cent of the second one.

II. Submaintenance. When a subject is being undernourished, a depletion of liver glycogen also takes place; and within a few days the carbohydrate of the metabolic mixture is equal to that of the diet. The subject must accordingly come into carbohydrate balance before precise values for energy exchange can be obtained by this method. 
An individual is assumed to be receiving the following diet: protein 70 grams; fat 100 grams; carbohydrate 100 grams. The insensible loss of weight is assumed to be 1027 grams per twenty-four hours, with a nitrogen excretion of 11.8 grams. Hence, 74 grams protein were oxidized, yielding 296 Calories. Since the subject had attained carbohydrate balance he was oxidizing 100 grams carbohydrate per twentyfour hours, from which he obtained 400 Calories.

From inspection of the constants previously cited, it is evident that the greatest portion of the difference between the weights of the carbon dioxide and oxygen is due to the combustion of carbohydrate, and, since the effect of fat and protein upon this difference tend to cancel each other, a first approximation of this difference may be obtained by considering only the carbohydrate:

(1) $\mathrm{CO}_{2}-\mathrm{O}_{2}$. (First approximation.)

100 grams carbohydrate $\times 0.41=41$ grams

(2) 1027 (Insensible loss) $-41=986$ grams insensible water. (First approximation.)

(3) $\frac{986 \times 0.58}{0.24}=2383$ Calories energy exchange (First approxi0.24 mation.)

(4) $2383-296$ (Calories from protein) -400 (Calories from carbohydrate) $=1687$ Calories from fat. (First approximation.)

(5) $\frac{1687}{9.54}=177$ grams fat. (First approximation.)

(6) $\mathrm{CO}_{2}-\mathrm{O}_{2} . \quad$ (Second approximation.)

$\begin{array}{lr}177(\text { Fat }) \times(-0.08)= & -14 \\ 100 \text { (Carbohydrate }) \times 0.41= & 41 \\ 74 \text { (Protein) } \times 0.08= & 6\end{array}$

(7) 1027 (Insensible loss) $-33=994$. Insensible water. (Second approximation.)

(8) $\frac{994 \times 0.58}{0.24}=2402$ Calories energy exchange. (Second approxi0.24 mation.)

Here again the second approximation is sufficiently accurate. 
III. Maintenance. In this case, over any protracted period, the carbohydrate of the metabolic mixture will be the same as that of the diet. The small inequalities on single days will balance each other over any few days. Accordingly, the difference between the weights of the carbon dioxide and oxygen may be calculated from the diet.

$I V$. Supermaintenance. The extra energy of such a diet may be deposited as any of the food stuffs. Since the amount of protein oxidized is determined by nitrogen excretion, deposition of extra protein does not concern us in the calculation of the metabolic mixture.

After a few days it may be safely assumed that no more glycogen will be deposited. Thereafter the extra energy contained in the carbohydrate and fat of the diet will be deposited as fat. Further, for purposes of calculation, it may be properly assumed that the carbohydrate of the diet is completely oxidized. However, it makes no difference in the calculation if a portion of the dietary carbohydrate is deposited as fat and the equivalent energy obtained from the oxidation of fat, as will be shown below.

Let us assume that a subject receives 100 grams of glucose and completely oxidizes it: The $\mathrm{CO}_{2}-\mathrm{O}_{2}$ for it would be $146.7-106.7=40$ grams. Let us next assume that when the same amount of heat is liberated, fifty per cent of it comes from the oxidation of the glucose itself; that the remainder of the glucose is first converted to fat and that the latter is then oxidized. The carbon dioxide and oxygen values for the $\mathbf{5 0}$ grams of carbohydrate burnt as such are 73.3 grams and $\mathbf{5 3 . 3}$ grams respectively. The remaining 50 grams of glucose are isocaloric with 19.8 grams of fat. However, the carbon content of this fat is only $\mathbf{7 5 . 2}$ per cent of that contained in $\mathbf{5 0}$ grams of glucose. Since the conversion of carbohydrate to fat is an endothermic reaction, the remaining 24.8 per cent of the $\mathbf{5 0}$ grams of glucose must be oxidized to furnish the energy for the reaction. This latter oxidation yields 18.2 grams of carbon dioxide and requires 13.2 grams of oxygen. The oxidation of the 19.8 grams of fat yields $\mathbf{5 5 . 1}$ grams of carbon dioxide and requires 56.9 grams of oxygen. But, in the conversion of 37.6 grams of carbohydrate to the 19.8 grams of fat, 16.9 grams of oxygen are liberated. Hence: 


\begin{tabular}{|c|c|c|}
\hline & $\underset{\text { grams }}{\mathrm{CO}_{2}}$ & $\underset{\text { grams }}{\mathrm{O}_{2}}$ \\
\hline 50 grams Glucose. . & 73.3 & 53.3 \\
\hline 19.8 grams Fat $\ldots \ldots \ldots \ldots \ldots \ldots \ldots \ldots \ldots \ldots \ldots$ & 55.1 & 56.9 \\
\hline \multirow{2}{*}{12.4 grams Carbohydrate...$\ldots \ldots \ldots \ldots \ldots \ldots$} & 18.2 & 13.2 \\
\hline & 146.6 & 123.4 \\
\hline Oxygen liberated. & $\theta$ & 16.9 \\
\hline & & 106.5 \\
\hline
\end{tabular}

Thus when the dietary carbohydrate is insufficient to furnish more than the total requirement of energy, and when it is impossible for the individual to store glycogen, it is legitimate to assume that the individual is oxidizing all of the ingested carbohydrate. In the unusual condition, when the individual is made to ingest carbohydrate whose calorific value is in excess of the total transformation of energy, special calculations will be needed.

Since it has now been shown that, under these conditions, all of the dietary carbohydrate is oxidized, the calculation proceeds as already described for submaintenance.

\section{SUMMARY}

(1) Eight individuals were fed, as nearly as possible, a maintenance diet while they continued to lead their usual lives.

(2) The twenty-four hourly insensible loss of weight was repeatedly determined and the average value for the insensible water calculated from it by subtracting the difference between the weights of the excreted carbon dioxide and the absorbed oxygen.

(3) It was shown that the heat removed by this water vapor was close to twenty-four per cent of the total heat production.

(4) A procedure was outlined for obtaining the carbon dioxide and oxygen values for any type of diet.

(5) Our results have shown that the determination of the twentyfour hourly insensible water furnishes an accurate method for calculating the heat production of individuals leading their routine lives. 


\section{BIBLIOGRAPHY}

1. Johnston, M. W., and Newburgh, L. H., J. Clin. Invest., 1930, viii, 147. The Determination of the Total Heat Eliminated by the Human Being.

2. Soderstrom, G. F., and DuBois, E. F., Arch. Int. Med., 1917, xix, 931. Clinical Calorimetry. XXV. The Water Elimination Through Skin and Respiratory Passages in Health and Disease.

3. Wiley, F. H., and Newburgh, L. H., J. Clin. Invest., 1931, x, 689. The Relationship Between the Environment and the Basal Insensible Loss of Weight. 